\title{
In ovo feeding of omega-3 fatty acids improved production traits, haematological parameters and immune response in broiler
}

\author{
Mahmood HM Amen \\ Sulaimani Polytechnic University, Kalar Technical Institute, Animal Health Department \\ Sulaimani- Kalar-Garmian
}

\begin{tabular}{|l|l|}
\hline $\begin{array}{l}\text { Article history } \\
\text { Received: 27 Dec, 2015 } \\
\text { Revised: 1 Feb, 2016 }\end{array}$ & $\begin{array}{l}\text { Abstract } \\
\text { The goal of the study was to investigate the influence of in ovo injection of omega-3 } \\
\text { fatty acids on performance traits, blood parameters and immune response in broilers. } \\
\text { At day 14 of incubation, 124 fertilized eggs (31 eggs for each group) were injected } \\
\text { with different levels of omega-3 fatty acid }(0.05,0.1 \text { and } 0.15 \text { ml) and one was kept as } \\
\text { a control. After hatching, 108 chicks were distributed into four groups }(27 \text { chicks for } \\
\text { each group) and each group was subdivided into three replicate (9 chicks for each } \\
\text { replicate). Results revealed that in ovo injection with omega-3 fatty acids on } 14 \text { day of } \\
\text { incubation resulted in significant increase in the hatchability and final body weight. } \\
\text { Haematology (WBC, RBC, PCV, Hb) improved significantly in treated chicks as } \\
\text { compared with control chicks. Furthermore, immune response of chicks treated with } \\
\text { mega-3 against ND disease increased significantly compared with non-injected chicks. } \\
\text { In conclusion, in ovo feeding of omega-3 fatty acids, at the levels of } 0.05,0.1 \text { and } 0.15 \\
\text { ml resulted in a significant improvement in production traits, haematological } \\
\text { parameters and immune response in broiler. } \\
\text { Keywords: In ovo injection; omega-3; immune status }\end{array}$ \\
\hline
\end{tabular}

To cite this article: Mahmood HM Amen, 2016. In ovo feeding of omega-3 fatty acids improved production traits, haematological parameters and immune response in broiler. Res. Opin. Anim. Vet. Sci., 6(1): 1-6.

\section{Introduction}

Omega-3 fatty acids ( $\omega-3$ fatty acids or n-3 fatty acids) are polyunsaturated fatty acids (PUFAs) with a double bond $(\mathrm{C}=\mathrm{C})$ at the third carbon atom from the end of the carbon chain (Scorletti and Byrne, 2013). The fatty acids have two ends, the carboxylic acid ($\mathrm{COOH}$ ) end, which is considered the beginning of the chain, thus "alpha", and the methyl (CH3) end, which is considered the "tail "of the chain. The three types of omega-3 fatty acids involved in human physiology are $\alpha$-linolenic acid (ALA), eicosapentaenoic acid (EPA) and docosahexaenoic acid (DHA). Marine algae and phytoplankton are primary sources of omega-3 fatty acids. Common sources of plant oils containing the omega-3 ALA fatty acid include walnut, edible seeds, oil, algal oil, and flaxseed oil, while sources of animal omega-3 EPA and DHA fatty acids include fish oils, egg oil, squid oils, and krill oil (Grey and Bolland, 2014; Zimmer, 2015; O'Connor, 2015).

Omega-3 fatty acids are important for normal metabolism. Mammals cannot synthesize omega-3 fatty acids, therefore, they are dependent for shorter-chain omega-3 fatty acid ALA (18 carbons and 3 double bonds) on feed sources and use it to form the long-chain omega-3 fatty acids. The essential fatty acids were given their name when researchers found that they are essential to normal growth in young animals (Van West and Maes, 2003).

*Corresponding author: Mahmood HM Amen, Sulaimani Polytechnic University, Kalar Technical Institute, Animal Health Department, Sulaimani- Kalar-Garmian; E-mail: mohmood.ameen@spu.edu.iq 
Recently, one of the new technologies introduced in poultry industry is in ovo feeding. In this method, liquid nutrients are injected into the embryos amniotic fluid (Herfiana, 2007). This mechanism is useful for embryo development because protein and energy are first derived from the yolk of the egg (Vieira, 2007). The importance of such a method appears more whenever we believe that birds have access to feed only after 36-48 hours which may subsequently influence the body weight and muscle development (Noy and Uni, 2009). Genetic selection, nutrition, and management of poultry flocks has improved over the last twenty years, however, hatchability of broiler eggs set in commercial hatcheries has not increased (Schaal and Cherian, 2007). In ovo technology may help to improve hatchability and health of the hatched chicks through feeding metabolic modulators to the developing embryo. Exogenous fatty acids and antioxidants provided to the developing embryo during incubation may enhance PUFAs, lipid, and antioxidant status of the chicken embryo (Schaal, 2008; Perez et al., 2010). It has also been reported that in ovo feeding subsequently improved hatchability, hatching weight, and growth performance (Bakyaraj et al., 2011; Selim et al., 2012) and immune response (Al-Rubaee, 2011; Selim et al., 2012).

The objective of this study was to determine the effects of in ovo feeding of exogenous supply of Omega-3 fatty acids on chick performance, blood parameters and immune response against New Castle disease (ND) in broiler.

\section{Materials and Methods}

\section{Eggs incubation and in ovo injection}

A total 120 fertile eggs were randomly selected. On the 14th day of incubation, the eggs were equally divided into four groups: control, $\mathrm{T} 1(0.1 \mathrm{ml}$ normal saline $), \mathrm{T} 2$ (egg injected with $0.05 \mathrm{ml}$ of omega-3), T3 (egg injected with $0.1 \mathrm{ml}$ ) and T4 (egg injected with $0.15 \mathrm{ml}$ ). The eggs in experimental groups were injected with omega-3 into the site of amnion through air cell which was identified by candling with an ultraviolet lamp, through a pinhole made at the broad end of the egg, deep $20 \mathrm{~mm}$ using $1 \mathrm{ml}$ automatic syringe with gage 20 needle. Also eggs were disinfected before and after every injection with $70 \%$ ethanol to prevent cross contamination between individual eggs. The pinhole site was sealed with nail paint immediately after injection. The injected eggs were returned to the incubator after injection. Figures 1, 2 and 3 show candling, in ovo feeding and sealing respectively.

\section{Birds care}

A total 108 hatched chicks were randomly distributed according to the plan as mentioned previously. Each experimental unit contained 27 chicks ( 9 chicks per replicate). The birds were reared on floor pens, each pen had three square meter with one hanging tube feeder and one suspended drinker. Feed and water were offered ad libitum and the light program was 23L/1D. Birds housed on floor pens and used straw as litter ( 5 birds per square meter). During the experiment, a two-phase feeding program consisted of a starter (121 days of age) and finisher (22-42 days of age) was provided to the broilers. Commercial feed was provided according to NRC (1994). The composition of experimental diet is shown in Table 1. All birds were vaccinated against the common diseases according to the prevention program for broiler chicken.

\section{Source of omega- 3 fatty acids}

Natural fish oil $(1000 \mathrm{mg})$ as a source of omega-3 fatty acids was obtained from Natural Assets, Omana Group, LLC. Garden Grove, CA 92841, USA, dissolved in liquid form (Gelatin capsule) containing $180 \mathrm{mg}$ EPA (Eicosapentaenoic Acid, $120 \mathrm{mg}$ DHA (Dococsahexaenoic Acid), gelatin, glycerine and purified water.

\section{Studied traits}

Hatchability was determined with the help of the following formula.

$$
\begin{gathered}
\text { Number of live chicks } \\
\text { Hatchability of Fertile eggs }=\text { - } \\
\text { Number of fertile eggs }
\end{gathered}
$$

\section{Production traits}

Initial body weight, body weight gain, feed intake, feed conversion ratio (FCR) and final body weight (7 weeks) were recorded. These traits were determined weekly (except initial boy weight) and the presented data as a total mean for the whole experimental periods (7 weeks).

\section{Haematological parameters}

Five individual blood samples were collected from each replicate for each analysis in a test tube with EDTA. Blood was collected from the main wing vein of the bird to determine the packed cell volume (PCV), Haemoglobin $(\mathrm{Hb})$, red blood cells (RBCs) and white blood cells (WBCs) count at day 14, 28 and 42 of bird's age according to Al-Daraji et al. (2008).

\section{Immune status}

To assess immune status, antibody titre of Newcastle disease virus (NDV) was measured by haemmaglutination inhibition test (HI). Serum was collected from the birds at $1^{\text {st }}, 3^{\text {rd }}$ and $6^{\text {th }}$ week of age from each group. Newcastle antibody levels in serum samples were analyzed according to Cunningham (1971) and Naji (2004). 


\section{Statistics analysis}

Data generated from experiment was carried out in a complete randomized design (Steel and Torrie, 1980). These data were subjected to ANOVA according to general linear model procedure of statistical analysis system software (SAS, 2001). The significant differences among means were determined by Duncan's multiple range tests (1955) with $(\mathrm{P} \leq 0.05)$ level of significance.

\section{Results}

The data of some performance traits of the birds in different treatments are showed in Table 2. The initial body weight of chicks ( $1^{\text {st }}$ day), boy weight gain and final body weight $\left(7^{\text {th }}\right.$ week) of hatched chicks were significantly $(\mathrm{P}<0.05)$ increased in treatment groups compared with the control group (T1). While, there was no significant difference in initial body weight and feed conversion rate among T2, T3 and T4. No significant difference was observed between T2 and T3 in body weight gain and final body weight, and same in between $\mathrm{T} 3$ and T4 in feed intake, while no significant difference was observed among T2, T3 and T4 regarding the hatchability. Some haematological traits (RBC, WBC, PCV and $\mathrm{Hb}$ ) from $2^{\text {nd }}$ to $6^{\text {th }}$ week of broiler chicken as affected by in ovo feeding with omega-3 are presented in Table 3. The result revealed that these traits increased significantly $(\mathrm{P}<0.05)$ in $\mathrm{T} 2$, T3 and T4 as compared with T1. Data of WBCs was presented in Table 3 which significantly $(\mathrm{P}<0.05)$ increased in $\mathrm{T} 3$ and $\mathrm{T} 4$, while no significant different between $\mathrm{T} 1$ and $\mathrm{T} 2$ in WBC at $4^{\text {th }}$ week of birds age, as well as between $\mathrm{T} 1$ and $\mathrm{T} 2$ in $\mathrm{Hb}$ at $4^{\text {th }}$ and $6^{\text {th }}$ week of age. Moreover, all of haematological parameters were improved significantly $(\mathrm{P}<0.05)$ in $\mathrm{T} 3$ and $\mathrm{T} 4$ compared with those hatched from control and T2 groups.

Furthermore, most of haematological parameters were improved significantly $(\mathrm{P}<0.05)$ in $\mathrm{T} 2$ as compared with control group during the current study. In addition, T4 showed higher value than other levels or treatments regarding these characteristics.

The effect of in ovo feeding with omega- 3 fatty acids on immune status are presented in Table 4 . The results revealed that in ovo feeding increased $(\mathrm{P}<0.05)$ bird's immunological response in $\mathrm{T} 2, \mathrm{~T} 3$ and $\mathrm{T} 4$ as compared with control group.

\section{Discussion}

The fatty acid reserve leads to improve embryo's ability to hatch and to perform; therefore, supplying embryos with exogenous nutrients in ovo could increase final body weight of broilers. Fat rich with omega-3 increase growth by activating bile production which leads to increased efficiency of digestion and absorption of diet in the intestines. This results is compatible with the findings of previous reports (El-Sayed and Hashim, 2000; Uni and Ferket, 2003; Al-Zuhairy and Alasadi, 2013).

Table 1: Ingredient of experimental diet (NRC, 1994)

\begin{tabular}{lcc}
\hline Ingredients & $\begin{array}{c}\text { Starter diet } \\
(\%)\end{array}$ & $\begin{array}{c}\text { Finished diet } \\
(\%)\end{array}$ \\
\hline Corn grains & 30 & 35 \\
Wheat grains & 10 & 13 \\
Soya bean meal & 43.7 & 35 \\
Flour & 10 & 10 \\
Vegetable oil & 1.5 & 2 \\
Vitamin Min. Premix & 4.8 & 5 \\
\hline
\end{tabular}

Calculated chemical analysis of experimental diet according to (NRC, (1994)

\begin{tabular}{lcc}
\hline $\begin{array}{c}\text { Analyzed } \\
\text { Ingredient }\end{array}$ & $\begin{array}{c}\text { Starter diet } \\
(1-22 \text { days) }\end{array}$ & $\begin{array}{c}\text { Finisher diet } \\
(22-42 \text { days })\end{array}$ \\
\hline Crude protein (\%) & 23.00 & 21.16 \\
Crude fat (\%) & 2.81 & 3.5 \\
Crude fiber (\%) & 2.84 & 2.71 \\
Ash (\%) & 5.3 & 4.19 \\
Dry matter (\%) & 88.08 & 87.99 \\
Metabolize energy (kcal/kg) & 2852.2 & 2962 \\
Methionine (\%) & 0.55 & 0.52 \\
Lysine (\%) & 1.3 & 1.17 \\
Methionine + Cysteine (\%) & 0.92 & 0.86 \\
Threonine (\%) & 0.55 & 0.77 \\
Tryptophan (\%) & 0.27 & 0.25 \\
Arginine (\%) & 1.56 & 1.41 \\
Valine (\%) & 1.06 & 0.98 \\
Isoleucine (\%) & 0.94 & 0.85 \\
Leucine (\%) & 1.79 & 1.67 \\
Calcium (\%) & 0.93 & 0.72 \\
Available phosphorus (\%) & 0.43 & 0.35 \\
Na (\%) & 0.17 & 0.16 \\
Cl & 0.27 & 0.27 \\
\hline
\end{tabular}

Table 2: Effect of different levels of in ovo feeding of omega-3 fatty acids on hatchability and some productive traits of broiler at different ages (Mean $\pm \mathrm{SE}$ )

\begin{tabular}{|c|c|c|c|c|}
\hline \multirow{2}{*}{ Traits } & \multicolumn{4}{|c|}{ Treatments $^{1}$} \\
\hline & $\mathrm{T} 1$ & $\mathrm{~T} 2$ & T3 & $\mathrm{T} 4$ \\
\hline Initial body weight $(\mathrm{g})\left(1^{\text {st }}\right.$ day $)$ & $39.90 \pm 1.04^{\mathrm{b}}$ & $41.19 \pm 1.99^{\mathrm{a}}$ & $41.12 \pm 1.16^{\mathrm{a}}$ & $40.96 \pm 1.21^{\mathrm{a}}$ \\
\hline Body weight gain $(\mathrm{g})$ & $2461 \pm 41.60^{\mathrm{c}}$ & $2779.4 . \pm 33.77^{b}$ & $2787.6 \pm 50.6^{\mathrm{b}}$ & $2898.4 \pm 55.3^{\mathrm{a}}$ \\
\hline Feed intake (g) (7 weeks) & $5515 \pm 59.6^{\mathrm{a}}$ & $5342 \pm 62.2^{\mathrm{b}}$ & $5302 \pm 66.7^{\mathrm{c}}$ & $5304 \pm 66.9^{c}$ \\
\hline Final body weight (g) ( 7 weeks) & $2491 \pm 22.91^{\mathrm{c}}$ & $2836 \pm 36.18^{b}$ & $2840 \pm 37.75^{\mathrm{b}}$ & $2933 \pm 76.37^{\mathrm{a}}$ \\
\hline Feed conversion ratio (FCR) & $2.24 \pm 0.02^{\mathrm{a}}$ & $1.92 \pm 0.01^{\mathrm{b}}$ & $1.91 \pm 0.04^{\mathrm{b}}$ & $1.87 \pm 0.02^{\mathrm{b}}$ \\
\hline Hatchability (\%) & $86.31 \pm 0.63^{\mathrm{b}}$ & $88.63 \pm 0.48^{\mathrm{a}}$ & $90.14 \pm 0.31^{\mathrm{a}}$ & $89.71 \pm 0.52^{\mathrm{a}}$ \\
\hline
\end{tabular}

${ }^{\mathrm{T}} \mathrm{T} 1=$ control group, T2, T3 and T4 denote in ovo feeding of $0.05,0.1 \& 0.15 \mathrm{ml}$ of omega-3 respectively. Different letters in the same row with different superscripts differ significantly $(\mathrm{P}<0.05)$. 
Table 3: Effect of different levels of in ovo feeding of omega-3 fatty acids on some haematological traits of broiler at 2, 4, and 6 weeks of age (Mean \pm SE)

\begin{tabular}{|c|c|c|c|c|c|}
\hline \multirow{2}{*}{ Hematological Traits ${ }^{2}$} & \multirow{2}{*}{$\begin{array}{c}\text { Age } \\
\text { (Weeks) }\end{array}$} & \multicolumn{4}{|c|}{ Treatments $^{1}$} \\
\hline & & $\mathrm{T} 1$ & $\mathrm{~T} 2$ & T3 & T4 \\
\hline \multirow{3}{*}{$\mathrm{RBC}\left(\times 10^{6} / \mathrm{mm}^{3}\right)$} & $2^{\text {nd }}$ & $2.615 \pm 0.39^{d}$ & $4.230 \pm 0.58^{\mathrm{c}}$ & $7.23 \pm 0.51^{b}$ & $9.61 \pm 0.49^{\mathrm{a}}$ \\
\hline & $4^{\text {th }}$ & $3.810 \pm 0.59^{\mathrm{d}}$ & $6.310 \pm 0.49^{\mathrm{c}}$ & $8.29 \pm 0.30^{\mathrm{b}}$ & $10.90 \pm 0.38^{\mathrm{a}}$ \\
\hline & $6^{\text {th }}$ & $4.75 \pm 0.20^{\mathrm{d}}$ & $6.83 \pm 0.67^{\mathrm{c}}$ & $8.87 \pm 0.29^{b}$ & $11.05 \pm 0.60^{\mathrm{a}}$ \\
\hline \multirow{3}{*}{$\mathrm{WBC}_{\mathrm{s}}\left(\times 10^{3} / \mathrm{mm}^{3}\right)$} & $2^{\text {nd }}$ & $4.24 \pm 0.42^{\mathrm{c}}$ & $8.03 \pm 0.90^{\mathrm{b}}$ & $10.40 \pm 1.10^{\mathrm{a}}$ & $10.87 \pm 0.50^{\mathrm{a}}$ \\
\hline & $4^{\text {th }}$ & $9.12 \pm 0.66^{\mathrm{b}}$ & $9.35 \pm 0.31^{\mathrm{b}}$ & $11.46 \pm 0.15^{\mathrm{a}}$ & $11.48 \pm 0.19^{\mathrm{a}}$ \\
\hline & $6^{\text {th }}$ & $13.40 \pm 0.83^{\mathrm{c}}$ & $17.22 \pm 1.46^{b}$ & $19.97 \pm 1.84^{\mathrm{a}}$ & $20.90 \pm 0.76^{\mathrm{a}}$ \\
\hline \multirow{3}{*}{ PCV (\%) } & $2^{\text {nd }}$ & $37.35 \pm 0.62^{c}$ & $42.38 \pm 2.30^{\mathrm{b}}$ & $48.47 \pm 0.76^{\mathrm{a}}$ & $48.20 \pm 0.94^{\mathrm{a}}$ \\
\hline & $4^{\text {th }}$ & $38.40 \pm 0.54^{\mathrm{c}}$ & $48.71 \pm 1.02^{b}$ & $50.54 \pm 1.26^{\mathrm{a}}$ & $49.89 \pm 1.35^{\mathrm{a}}$ \\
\hline & $6^{\text {th }}$ & $47.49 \pm 1.67^{\mathrm{b}}$ & $50.55 \pm 0.68^{\mathrm{a}}$ & $51.04 \pm 0.90^{\mathrm{a}}$ & $51.49 \pm 0.70^{\mathrm{a}}$ \\
\hline \multirow{3}{*}{$\mathrm{Hb}(\mathrm{g} / \mathrm{dl})$} & $2^{\text {nd }}$ & $8.11 \pm 0.53^{\mathrm{b}}$ & $9.88 .0 \pm 2.60^{\mathrm{a}}$ & $10.25 \pm 0.48^{\mathrm{a}}$ & $10.55 \pm 0.88^{\mathrm{a}}$ \\
\hline & $4^{\text {th }}$ & $10.46 \pm 0.73^{c}$ & $10.57 \pm 0.60^{c}$ & $12.03 \pm 0.35^{\mathrm{b}}$ & $14.06 \pm 1.48^{\mathrm{a}}$ \\
\hline & $6^{\text {th }}$ & $12.11 \pm 0.22^{\mathrm{b}}$ & $12.18 \pm 0.188^{\mathrm{b}}$ & $14.13 \pm 0.12^{\mathrm{a}}$ & $14.08 \pm 0.27^{\mathrm{a}}$ \\
\hline
\end{tabular}

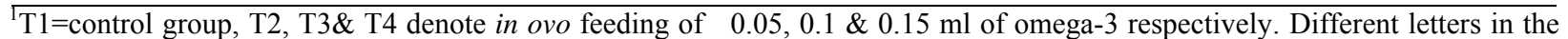
same row differ significantly $(\mathrm{P}<0.05)$

Table 4: Effect in ovo feeding of omega-3 fatty acids on antibodies titre against Newcastle disease virus (NDV) assessed by Hem inhibition test $(\mathrm{HI})$ at $1^{\text {st }}, 3^{\text {rd }}$ and $6^{\text {th }}$ weeks of age of broiler chicken (Geometric mean ${ }^{1} \pm \mathrm{SE}$ )

\begin{tabular}{lccccc}
\hline Trait & Age (week) & ${ }^{2}$ T1 (control) & T2 & T3 & T4* \\
\hline Immune status(Titter) & $1^{\text {st }}$ & $3.30 \pm 0.36^{\mathrm{C}}$ & $5.23 \pm 0.45^{\mathrm{A}}$ & $5.40 \pm 0.34^{\mathrm{A}}$ & $5.53 \pm 0.21^{\mathrm{A}}$ \\
HI Test against ND & $3^{\text {rd }}$ & $3.54 \pm 0.30^{\mathrm{C}}$ & $4.73 \pm 0.44^{\mathrm{A}}$ & $4.71 \pm 0.65^{\mathrm{A}}$ & $5.26 \pm 0.610^{\mathrm{A}}$ \\
& $6^{\text {th }}$ & $6.03 \pm 0.45^{\mathrm{C}}$ & $7.06 \pm 0.25^{\mathrm{A}}$ & $7.13 \pm 0.23^{\mathrm{A}}$ & $7.38 \pm 0.35^{\mathrm{A}}$ \\
\hline
\end{tabular}

${ }^{\mathrm{T}}$ Geometric mean $=($ the average of the Logs 10$) ;{ }^{2} \mathrm{~T} 1=$ control group, T2, T3\& T4 denote in ovo feeding of $0.05,0.1 \& 0.15 \mathrm{ml}$ of omega-3 respectively. *Means in a same row without common letter differ significantly $(\mathrm{P} \leq 0.05)$.

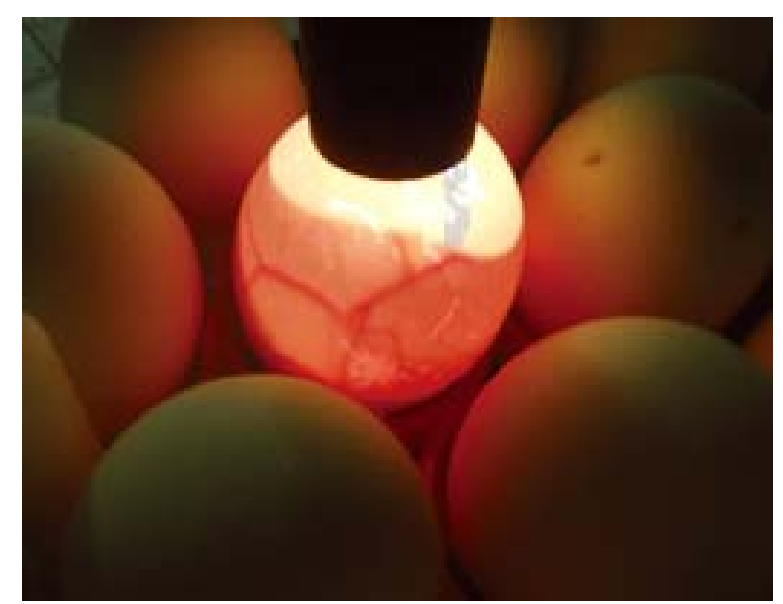

Fig. 1: Fertile egg by candling with a hand ultraviolet lamp at day 11 of egg incubation.

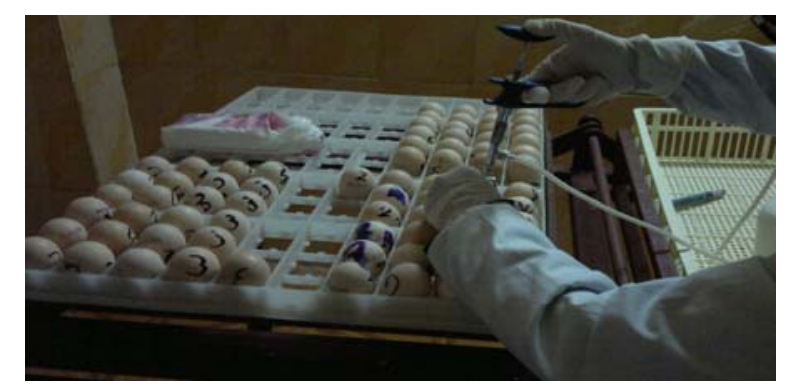

Fig. 2: Show the process of in ovo feeding by automatic syringe.

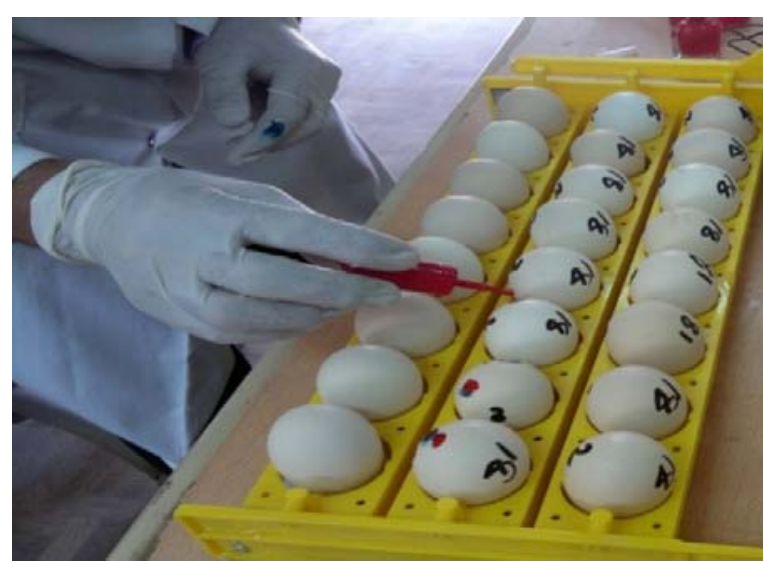

Fig. 3: Sealing the injection site of eggs with nail paint.

In our study, hatchability was improved with in ovo feeding of omega-3 fatty acids which might ameliorate the production of energy during embryo-genesis. Recently, it has been shown that nutrient administration through in ovo injection could be considered as an alternative method to improve hatchability (Amen, 2015).

The improvement in red blood cells count occurs in treatment groups may be due to fast growth and an increase in live body weight which make the birds suffered from metabolic stress represented by deficiency of oxygen in the blood and this leads to an increase production of red blood cells to meet the requirement of oxygen (Price et al., 1998). The haematological results in our study are in agreement with Al-Daraji et al. (2010) 
who showed that flaxseed (source of omega-3) increased erythrocyte number, $\mathrm{PCV}, \mathrm{Hb}$ and leukocyte number. Our results are also in agreement with some of the previous reports (Bond et al.; 1997; Kadhim, 2010; Radwan et al.; 2012; Jameel, 2013; Al-Zuhairy and Jameel, 2014). The increase of antibody titer against ND virus could be due to omega-3 components are important for the development of the immune cell structure and eicosanoid formation. In addition, omega-3 PUFAs have anti-inflammatory by decreasing the release of pro-inflammatory eicosanoids and cytokines (Al-zuhairy and Jameel, 2014). Korever and Klasing (1997) found that increasing dietary omega-3 inhibited the conversion of omega- 6 to long chain omega6 fatty acids in immune tissues. Also, competition between omega- 6 and omega- 3 in conversion to longchain fatty acids and eicosanoids in immune tissues most likely contributed to improved antibody production in response to vaccines (Wang et al., 2002; Puthpongsiriporn and Scheideler, 2005). Furthermore, Wang et al. (2004) reported that omega- 6 to omega- 3 ratio may influence the binding activity of IgG-receptor on the yolk sac membrane and thus it affects the maternal-embryo transfer of yolk IgG. This result is in agreement with the suggestion of Bhanja et al. (2006), Bakyaraj et al. (2011), Al-Zuhairy and Alasadi (2013) who evaluated the early post-hatch growth and immunity through in ovo. Enrichment of cell membrane with omega-3 PUFAs could decrease inflammatory response, improve growth rate, erythropoiesis, leucopoiesis and increase specific immunity (Korever and Klasing, 1997).

In conclusion, in ovo feeding with omega-3 has beneficial impact on performance traits, blood parameters and immune status.

\section{References}

Al-Daraji HJ, Al-Hassani AS, Al-Mashadani HA, AlHayani WK, Mirza HA (2010) Effect of dietary supplementation with Sources of omega-3 and Omega-6 fatty acids on certain blood characteristics of laying quail. Inter J Poult Sci 9: 689-694.

Al-Daraji HJ, Al-Hayani, WK, Al-Hassani AS (2008) Avian hematology. Ministry of Higher Education \& scientific Research, University of Baghdad, College of Agriculture.

Al-Rubaee AHQ (2011) The effect of omega -3 (flaxseed and fish oil) and vitamin $\mathrm{E}$ on immune response of Newcastle disease and productive parameters of two line of Japanese quails. Thesis. College of Veterinary Medicine. Baghdad University, Baghdad, Iraq.

Al-Zuhairy MA, Alasadi YJ (2013) Effect of in ovo injection with Newcastle disease vaccine, multivitamins $\mathrm{AD} 3 \mathrm{E}$, and omega-3 on performance and immune response of broiler. Inter J Adv Biol Res 3: 208-211.
Al-zuhairy MA, Alasadi YJ (2013) Effect of in ovo injection with Newcastle disease vaccine, multivitamins AD3E, and omega-3 on performance and immune response of broiler. Inter J Adv Biol Res 3: 208-211.

Al-zuhairy MA, Jameel YJ (2014) Effect of ND Vaccine ,Multivitamin AD3E, and Omega-3 on Performance and Immune Response of Broilers. Mirror of Research in Veterinary Sciences and Animals (MRVSA) 3: 42-50.

Amen MHM (2015) In ovo injection of omega-3 fatty acides improve hatchability and chick performance. Published in $2^{\text {nd }}$ scientific conference at Gramian University in May $7^{\text {th }}$ 2015. Garmain-Iraq.

Bakyaraj S, Subrat KB, Samir M, Banabihari D (2011) Modulation of post-hatch growth and immunity through in ovo supplemented nutrients in broiler chickens. J Sci Food Agric 12: 313-320.

Bhanja SK, Mandal AB, Agarwal SK, Majumdar S (2006) Modulation of post hatch growth and immune competence through in ovo injection of vitamin $\mathrm{E}$ and linoleic acid. (Supplement, European Poultry Conference. World's Poult Sci J 62: 325.

Bond JM, Julian RJ, Squires EJ (1997) Effect of dietary flaxseed on broiler growth, erythrocyte deformability, and fatty acid composition of erythrocyte membranes. Can J Anim Sci 77: 279-286.

Cunningham CH (1971) Virologia practica, $6^{\text {th }}$ ed. Zaragoza, Acribia, 260p. Naji SAH 2004. Poultry Health Management. Ministry of Higher Education \&scientific Research, University of Baghdad, College of Agriculture, department of Animal resources.

Duncan DB (1955) Multiple range and multiple F-test. Biometrics 11:1-42.

El-Sayed EM, Hashim ME (2000) Effect of Nigella sativa on the immune response to Eimeria vaccination in chicken. Egypt J Agri Res 78: 231- 239.

Grey A, Bolland M (2014) Clinical Trial Evidence and Use of Fish Oil Supplements". JAMA Int Med 174: 460-462.

Herfiana IM (2007) The effect of Glutamine, Dextrin and Its Combination Through In Ovo Feeding on Immune Response, Blood Profiles and The Carcass Composition of MaleBroiler Chicken. Msc thesis. Sekolah Pascasarjana, Institute pertanin, Bogor.

Jameel YJ (2013) The effect of in-ovo injection with Newcastle disease vaccine, multivitamins AD3E and omega-3 oil on subsequence productive performance and some physiological parameters of broiler chicks. $\mathrm{Ph} . \mathrm{D}$. Dissertation in science of poultry hygiene. College of Veterinary Medicine. University of Baghdad. Iraq.

Kadhim SK (2010) The effect of adding cod liver oil to different protein sources of broilers diet on the production efficiency and health status. M.Sc. Thesis 
in science of public health. College of Veterinary Medicine. University of Baghdad. Iraq. (In Arabic).

Korever DR, Klasing KC (1997) Dietary fish oil alters specific and inflammatory immune responses in chicks. J Nutr 127: 2039-2046.

National Research Council (NRC) (1994) Nutrient requirements of poultry.9th Ed. National Academy Press. Washington DC USA.

Noy Y, Uni Z (2009) Early Nutritional Strategies. 147152. www.cabi.org.

O'Connor A (2015) Fish Oil Claims Not Supported by Research. New York Times.Retrieved October 11, 2015. Cited by www.ekipedia the free encyclopedia.

Perez TI, Zuidhof MJ, Renema RA, Curtis JM, Ren Y, Betti M (2010) Effects of vitamin $E$ and organicselenium on oxidative stability of $\omega-3$ enriched darkchicken meat during cooking. Journal of Food Science, 75: 25-34.

Price NT, Jackson VN, Halestrap AP (1998) Cloning and sequencing of four new mammalian monocarboxylate transporter (MCT) homologues confirms the existence of a transporter family with an ancient past. Biochem J 329: 321-328.

Puthpongsiriporn U, Scheideler SE (2005) Effects of dietary ratio of linoleic to linolenic acid on performance, antibody production and in vitro lymphocyte proliferation in two strains of Leghorn pullet chicks. Poult Sci 84: 846-857.

Radwan NL, Abd El-Samad MH, Sherin A (2012) Effects of different dietary rations of linoleic acid to alinolenic acid on productive performance, immunity of laying hens and egg yolk fatty acid composition. Egypt Poult Sci 32: 163-188.

SAS (2001) SAS/STAT Users Guide, Version 6.12. SAS Inst Inc, Cary NC. Edgar. 2007. Omega-3 fatty acids: Chemical stracture. Cited by www.wikipedia,the free encyclopedia.
Schaal T, Cherian G (2007) A survey of the hatchability of broiler and Turkey eggs in the United States from 1985 through 2005. Poult Sci 86: 598-600.

Schaal TP (2008) The effect of in ovo feeding of fatty acids and antioxidants on broiler chicken hatchability and chick tissue lipids. Honors Bachelor of Science (HBS), University Honors College, Oregon State University.

Scorletti E, Byrne CD (2013) Omega-3 fatty acids, hepatic lipid metabolism, and nonalcoholic fatty liver disease. Ann Rev Nutr 33: 231-48.

Selim Sh A, Gaafar KM, El-ballal SS (2012) Influence of in ovo administration with vitamin $\mathrm{E}$ and ascorbic acid on the performance of Muscovy ducks. Emir J Food Agric 24: 264-271.

Steel RGD, Torrie JH (1980) Principle and procedures of statistics.2nd Ed. McGraw-Hill Book Co. Inc. New York. USA, pp: 183-193.

Uni Z, Ferket PR (2003) Enhancement of development of oviparous species by in ovo feeding. US Regular Patent US 6:B2.

Van West D, Maes M (2003) Polyunsaturated fatty acids in depression. Acta Neuropsych 15: 15-21.

Vieira SL (2007) Chicken Embryo Utilization of Egg Micronutrients. Braz J Poult Sci 9: 1-8.

Wang Y, Ajugah AO, Sunwoo HH, Cherian G, Sim JS (2002) Maternal dietary n-3 fatty acids alter the spleen fatty acid composition and bovine serum albumin induced wing web swelling in broilers. Poult Sci 81: 1722-1727.

Wang YW, Sunwoo H, Cherian G, Sim JS (2004) Maternal dietary ratio of linoleic acid to $\alpha$ - linolenic acid affects the passive immunity of hatching chicks. Poult Sci 83: 2039-2043.

Zimmer C (2015) Inuit Study Adds Twist to Omega-3 Fatty Acids (HealthStory). New York Times. Cited by www. wekipedia the free encyclopedia. 